\title{
Monocrotophos Degradation Potential of Bacterial Isolates Isolated from Agricultural Soils of Visakhapatnam Dist.
}

\author{
Sri Lakshmi Balakrishnan* and P.V.V. Prasada Rao \\ Department of Environmental Sciences, Andhra University, Visakhapatnam - 530 003, India.
}

\begin{abstract}
The present study reports the biodegradation studies of Monocrotophos in agricultural soils of Visakhapatnam district. Bacterial strains were isolated from agricultural soils of Visakhapatnam dist. The isolates based on their morphological, biochemical and molecular characteristics were identified as Bacillus aryabhatta Strain ENP 3, Bacillus drentensis strain ENA1, Bacillus firmus Strain EN5C, and Staphylococcus vitulinus Strain EN5F. These four strains were isolated for the first time in this region. The degradation potential of the organisms for Monocrotophos as the only carbon source were studied and also the influence of Cow dung manure and NPK fertilizer on the growth and degradation capacity of organisms were studied. Degradation potential in media for individual organism as well as consortia was studied using spectrophotometric analysis. LC-MS was used to detect the degradation potential of microbial consortia in soil and also know the intermediate metabolites formed during degradation. It was found that the bacterial consortium has the highest degradation potential compared to individual organisms and Bacillus aryabhattai strain ENP3 has higher is degradation potential for Monocrotophos compared to other organisms.
\end{abstract}

Keywords: Biodegradation, Monocrotophos, Bacterial Isolates, Cow dung manure, NPK fertilizer, Spectrophotometric analysis, LC-MS.

*Correspondence: srilakshmi.balakrishna@gmail.com; +91-9703933435

(Received: 28 January 2019; accepted: 01 March 2019)

Citation: Sri Lakshmi Balakrishnan and P.V.V. Prasada Rao, Monocrotophos Degradation Potential of Bacterial Isolates Isolated from Agricultural Soils of Visakhapatnam Dist., J Pure Appl Microbiol., 2019; 13(1):393-402 doi: 10.22207/JPAM.13.1.43

C The Author(s) 2019. Open Access. This article is distributed under the terms of the Creative Commons Attribution 4.0 International License which permits unrestricted use, sharing, distribution, and reproduction in any medium, provided you give appropriate credit to the original author(s) and the source, provide a link to the Creative Commons license, and indicate if changes were made. 


\section{INTRODUCTION}

India, despite its progress in various fields, is primarily considered as anagro based economy with more than $60 \%$ of its population depending mainly on agriculture for their subsistence. Due to pest infestation, more than $30 \%-40 \%$ of the crop produce is damaged every year. In the process of development of an effective pest control strategy, deployment of pesticides has become inevitable, regardless of their known toxicity. Utilization of pesticides in India is about 3\% of the total world consumption and is increasing at the rate of $2-5 \%$ per annum ${ }^{1}$. These pesticides are categorized into various groups such as, insecticides, fungicides, herbicides etc. About $98 \%$ of sprayed insecticides and $95 \%$ of herbicides reach a destination other than their target species including non-target species, air, water, bottom sediments, and food leading to food chain toxicity ${ }^{2}$. The use of these pesticides in many developing countries is not being regulated leading to accumulation of residues in various food which possess health hazards. Many studies have reported the presence of organophosphate insecticides as the main pesticide residue found in food chains ${ }^{3,4}$. Organophosphate insecticides such as Monocrotophos, Parathion, Malathion, Methylparathion are well known for their bioaccumulation and neurotoxic properties, because they act on the enzyme acetyl cholinesterase ${ }^{5}$.

Monocrotophos (MCP) (Dimethyl (E)1-methyl-2 methyl carbamoyl vinyl phosphate) is a broad-spectrum organo phosphate (OP) insecticide and acaricide which works systemically and on contact. Monocrotophosis widely used in agriculture and house-hold, particularly effective against Lepidoptera, Homoptera, and certain Coleoptera. Mono-crotophos affects the central nervous system by inhibiting cholinesterase (AchE), which breaks down acetylcholine, a chemical that serves as neurotransmitters alongside other choline-based esters. Serious exposure may target the eyes, respiratory system, cardiovascular system and reproductive system ${ }^{6}$. Due to its toxicity to non- target organisms it is banned in many developed countries but is still widely used in developing countries like India. The widespread use of Monocrotophos is found to accumulate in soil and gets leached into water bodies, making the aquatic environment polluted and is found to be toxic to non-target organisms. It has been classified as extremely hazardous, with an LD50 value of $20 \mathrm{mg} / \mathrm{kg}$ for mammals ${ }^{7}$. The half-life of Monocrotophos in soil was reported to be 40-60 days ${ }^{8}$. Monocrotophos is easily soluble in water and therefore has potential to contaminate ground water. In the environment the degradation of Monocrotophos pathways are non-cholinesterase inhibiting and of low toxicity. Volatilization appears to be the major factor in the rapid loss of residues followed by hydrolysis and oxidation of Monocrotophos application. Monocrotophos and its metabolites are rapidly degraded in soil, mainly biologically, to complete mineralization. They will not accumulate in the environment under normal use conditions ${ }^{9}$.

The present study is focused on the degradation of Monocrotophos by bacterial isolates isolated from the agricultural soils of Visakhapatnam district. The degradation potential of both individual isolates as well as consortium has been studied; also the impact of cow dung manure and NPK on the growth of organisms was studied.

\section{MATERIALS AND METHODS Collection of soil samples}

Soil samples were collected from four agriculture practicing villages of Visakhapatnam District, Andhra Pradesh, India. Control sample was taken from an area where agriculture is no longer practiced. All the sample sites were dry fields. The Soil samples were collected in quadrilateral method from a depth of $0-15 \mathrm{~cm}$ in sterile sealed plastic bags. Each sample bag was labelled properly with soil type and location. The experimental samples were stored in cool and moist place for the purpose of microbial survival. The soil samples were dried in shade for $24 \mathrm{hrs}$,

Table 1. GPS Location of the soil samples collected

\begin{tabular}{|c|c|c|}
\hline & Place & GPS Location \\
\hline \multirow[t]{2}{*}{1} & (Control) & $17^{\circ} 36^{\prime} 58.71^{\prime \prime} \mathrm{N} 83^{\circ} 04^{\prime} 52.19^{\prime \prime} \mathrm{N}$ \\
\hline & Sample 1 & \\
\hline 2 & Sample 2 & $17^{\circ} 37^{\prime} 19.86^{\prime \prime} \mathrm{N} 83^{\circ} 04^{\prime} 43.61^{\prime \prime N}$ \\
\hline 3 & Sample 3 & $17^{\circ} 33^{\prime} 05.85^{\prime \prime} \mathrm{N} 83^{\circ} 58^{\prime} 44.22^{\prime \prime} \mathrm{N}$ \\
\hline 4 & Sample 4 & $17^{\circ} 47^{\prime} 28.85^{\prime \prime} \mathrm{N} 83^{\circ} 06^{\prime} 51.07^{\prime \prime} \mathrm{N}$ \\
\hline 5 & Sample 5 & $17^{\circ} 47^{\prime} 39.82^{\prime \prime N ~} 83^{\circ} 11^{\prime} 46.29^{\prime \prime N}$ \\
\hline
\end{tabular}


the clods were crushed and the entire quantity is passed through $2 \mathrm{~mm}$ stainless steel sieve. The physico-chemical properties of the soil such as $\mathrm{pH}$, $\mathrm{EC}$, soil texture and soil moisture were determined using UF/IFAS methods ${ }^{10}$. Nitrogen was estimated using Kjeldahl ${ }^{11}$; Phosphorus was determined by Bray and Kurtz method ${ }^{12}$ and Potassium was estimated by the method asreported by Black ${ }^{13}$. Table 1 show the GPS location of the soil sample locations and Table 2 depicts the physico-chemical properties of the soil samples collected.

\section{Isolation of bacteria}

Isolation of bacteria was done using serial dilution plate technique and subsequent dilutions were made up to $10^{7}$ times. Each diluted sample was spread over the surface of nutrient agar plates in duplicate and incubated at $37^{\circ} \mathrm{C}$ for 72 hours. The strains of bacteria were selectively isolated from the mixed population of microbes growing on the nutrient agar medium by single colony isolation. Isolates were selected based on their morphological characteristics such as colour, margin, elevation, and optical features of the colonies, shape and arrangements of the vegetative cells ${ }^{14}$. Streak plate method was employed to isolate pure cultures and maintained for further studies. Biochemical analyses of all the isolates were carried out according to Bergey's Manual of Determinative Bacteriology ${ }^{15}$. Confirmation of the genus and species level was done using 16s rRNA sequencing and molecular analysis was done using $16 \mathrm{~s}$ rDNA technique using universal primer $27 \mathrm{~F}$ AGAGTTTGATCMTGG CTCAG 20, 1492 R TACGGYTACCTTGTTA CGACTT2'.

\section{Chemicals}

Commercial grade insecticide Monocrotophos (50\% E.C)andNPK fertilizer having a ratio of 19:19:19 was obtained from Sri Sai
Agrochemicals Visakhapatnam. Dried cow dung manure was collected from Simhachalam Goshala, a dedicated unit for the protection of cows. All other chemicals and reagents used in this experiment were of analytical grade and procured from Hi-Media. Double distilled water was used throughout the experiment.

\section{Enrichment of isolates}

Nutrient medium supplemented with Monocrotophos was used to grow the Isolates and incubated for $24 \mathrm{hrs} .1 \%$ of the cultures were transferred to minimal salt media (MSM) containing $0.5 \mathrm{~g}$ of $\mathrm{K}_{2} \mathrm{HPO}_{4}, 0.04 \mathrm{~g}$ of $\mathrm{KH}_{2} \mathrm{PO}_{4}, 0.1$ $\mathrm{g}$ of $\left(\mathrm{NH}_{4}\right)_{2} \mathrm{SO}_{4}, 0.05 \mathrm{~g}$ of $\mathrm{MgSO}_{4}, 0.01 \mathrm{~g}$ of $\mathrm{FeSO}_{4}$ and $0.5 \mathrm{~g}$ of $\mathrm{NaCl} /$ litre at $\mathrm{pH} 7.0$ containing Monocrotophos as the sole source of carbon. The cultures grown on MSM were used for further studies.

Optimization of $\mathrm{pH}$, Temperature and Pesticide concentration

\section{Pesticide concentration}

The Isolates were streaked in MSM agar containing $10-500 \mathrm{ppm}$ of Monocrotophos, The isolated organisms were grown in MSM at different pHof $6.0,7.0$ and 8.0 and temperature of $25^{\circ} \mathrm{C}$, $37^{\circ} \mathrm{C}$ and $45^{\circ} \mathrm{C}$ in MSM containing $200 \mathrm{mgL}-1$ of Monocrotophos. The plates were incubated at room temperature for 24 hours and growth was observed. MSM without Monocrotophos, served as control.

\section{Growth kinetics}

Turbid metric method was used to determine the growth kinetics. The organisms selected were grown in sterile nutrient broth containing Monocrotophos as the sole carbon source. The effects of NPK and cow dung on the growth pattern of the organisms were studied. Individual sterile broth containing inoculates

Table 2. Physico - Chemical Properties of soil samples

\begin{tabular}{|c|c|c|c|c|c|c|c|}
\hline \multirow[t]{2}{*}{ Samples } & \multirow[t]{2}{*}{$\mathrm{pH}$} & \multirow{2}{*}{$\begin{array}{c}\mathrm{EC} \mu \mathrm{s} / \\
\mathrm{cm}\end{array}$} & \multirow{2}{*}{$\begin{array}{c}\text { Soil } \\
\text { texture }\end{array}$} & \multirow{2}{*}{$\begin{array}{c}\text { Soil } \\
\text { Moisture }\end{array}$} & \multicolumn{3}{|c|}{ Available (Kg/ha) } \\
\hline & & & & & $\mathrm{N}$ & $P$ & $\mathrm{~K}$ \\
\hline Sample 1 & 7.8 & 197 & Sandy soil & 3.7 & 165.2 & 21.2 & 270.0 \\
\hline Sample 2 & 7.3 & 220 & Sandy soil & 5.8 & 186.3 & 29.3 & 340.0 \\
\hline Sample 3 & 7.1 & 207 & Sandy soil & 5.7 & 196.2 & 32.4 & 320.2 \\
\hline Sample 4 & 7.5 & 217 & Sandy soil & 6.2 & 207.0 & 39.2 & 370.7 \\
\hline Samplec5 & 7.9 & 244 & Sandy soil & 6.8 & 170.3 & 31.5 & 283.2 \\
\hline
\end{tabular}


without the addition of carbon source, NPK and Cow dung manure was set as control.

Bioremediation studies in media

The bioremediation efficacy of the selected organisms was observed by growing the four organisms in nutrient broth containing Monocrotophos $\left(500 \mathrm{mgL}^{-1}\right)$ in $500 \mathrm{ml} \mathrm{Erlenmeyer}^{2}$ flask. After $24 \mathrm{~h}$ of incubation, about $1 \%$ of culture was transferred to minimal salt media (MSM). Monocrotophos was used as the sole carbon source and incubated on a rotary shaker at 150 rpm for 7 days at room temperature. Samples from culture flasks were centrifuged at 3,500 rpm for 15 min to obtain cell free extract. Spectrophotometric readings of the cell free extract were taken on daily basis/ $24 \mathrm{~h}$ for 7 days.

Bioremediation studies of the selected bacterial consortium along with addition of NPK fertilizer and cow dung manure (CDM).

The selected Bacterial consortium was grown in an erlynmayer flask $(500 \mathrm{ml})$ containing nutrient broth with Chlorpyrifos $\left(500 \mathrm{mgL}^{-1}\right)$ as sole carbon source. After $24 \mathrm{~h}$ of incubation about $1 \%$ of culture is transferred to another erlynmayer flask $(500 \mathrm{ml})$ containing minimal salt media (MSM) with Chlorpyrifos. About 2.5gms of NPK 19-19-19 was taken and diluted thoroughly in distilled water and added to MSM. To another flask about 50gms of sterilized and dried cow dung manure ${ }^{16}$ was taken and diluted thoroughly in distilled water and added to MSM. The flask is incubated on a rotary shaker at $150 \mathrm{rpm}$ for 7 days at room temperature. Media containing Chlorpyrifos and NPK and Chlorpyrifos and Cow dung manure without addition of inoculates were set as control. Samples from culture flask were centrifuged at 4,200 rpm for 15 min to obtain cell free extract. Spectrophotometric readings of the cell free extract were taken on daily bases or $24 \mathrm{~h}$ for 7 days. All the experiments were carried out in triplicates.

In soil

The soils collected from agricultural fields, were subjected to three-fold autoclaving at $15 \mathrm{lbs}$ pressure $\& 121^{\circ} \mathrm{C}$ for $30 \mathrm{~min}$ for sterilization before analysis. $500 \mathrm{~g}$ of these sterilized soils were taken into plastic bags. Monocrotophos $(500 \mathrm{mg} /$ $\mathrm{kg}$ ) was added to each soil bag and the soil was thoroughly mixed to ensure uniform concentration of pesticides. Bacterial isolates were grown in nutrient broth medium. After $24 \mathrm{~h}$ incubation, the organisms were transferred to individual MSM with pesticides. The organisms were inoculated with the contaminated soilsat $1 \times 10^{8} \mathrm{cfu} / \mathrm{g}$. Soil samples (15 g) were recovered and extracted with acetonitrile solvent. Each of the extract was analysed by LC-MS for every 4 days. Pesticide contaminated soils without organisms were kept as controls.

\section{LC-MS}

Soil samples were collected from each bag for pesticide analysis. 15 grams of soil samples were weighed into a 250-ml Erlenmeyer flask and $20 \mathrm{ml}$ of HPLC grade acetonitrile was successively added with continuous shaking for $30 \mathrm{~min}$ on a rotary shaker at $120 \mathrm{rpm}$. Then, the samples were allowed until the soil had settled and the

Table 3. Tolerance of Monocrotophos concentration by the four isolates

\begin{tabular}{|c|c|c|c|c|}
\hline 10 ppm & ++ & ++ & ++ & ++ \\
\hline 20 ppm & ++ & ++ & ++ & ++ \\
\hline 80 ppm & ++ & ++ & ++ & ++ \\
\hline 100 ppm & ++ & ++ & ++ & ++ \\
\hline 200 ppm & + & ++ & + & ++ \\
\hline 300 ppm & + & ++ & + & + \\
\hline
\end{tabular}

++ Active growth, + slight growth 
clear supernatant liquid was used to determine the pesticide concentration by LC-MS as per the following conditions: column: Agilent C20 (230 x $5.4 \mathrm{~mm}$ ), detector: programmable variable wave length UV detector, flow rate: $1 \mathrm{~mL} / \mathrm{min}$, mobile phase: acetonitrile + ammonium acetate (90:10), $\mathrm{pH} 5.5$ and injection volume: $50 \mu \mathrm{L}$.

LC-MS determination was done to identify the intermediates and final degradation compounds.

\section{RESULTS}

\section{Identification of bacterial isolates}

The morphological and biochemzical characterization of soil bacteria has identified a total of 24 bacterial isolates out of which four bacterial isolates showed distinct morphological features. Further, biochemical results of these strains using 16s rDNA sequence analysis against BLAST search showed that the bacterial isolates were Bacillus aryabhatta Strain ENP 3, Bacillus drentensis strain ENA1, Bacillus firmus Strain EN5C, and Staphylococcus vitulinus Strain EN5FThese organisms were isolated for the first time in Visakhapatnam district. The sequence of the four isolates was submitted to gene bank and the following accession numbers KY399763, KY399764, KY399766, KY399767 were obtained.

\section{Bio-remediation studies}

Biodegradation of Monocrotophos was studied using the four organisms; Bacillus aryabhattai, Bacillus drentensis, Bacillus firmus, and Staphylococcus vitulinus which were isolated from the agricultural soils for the first time in
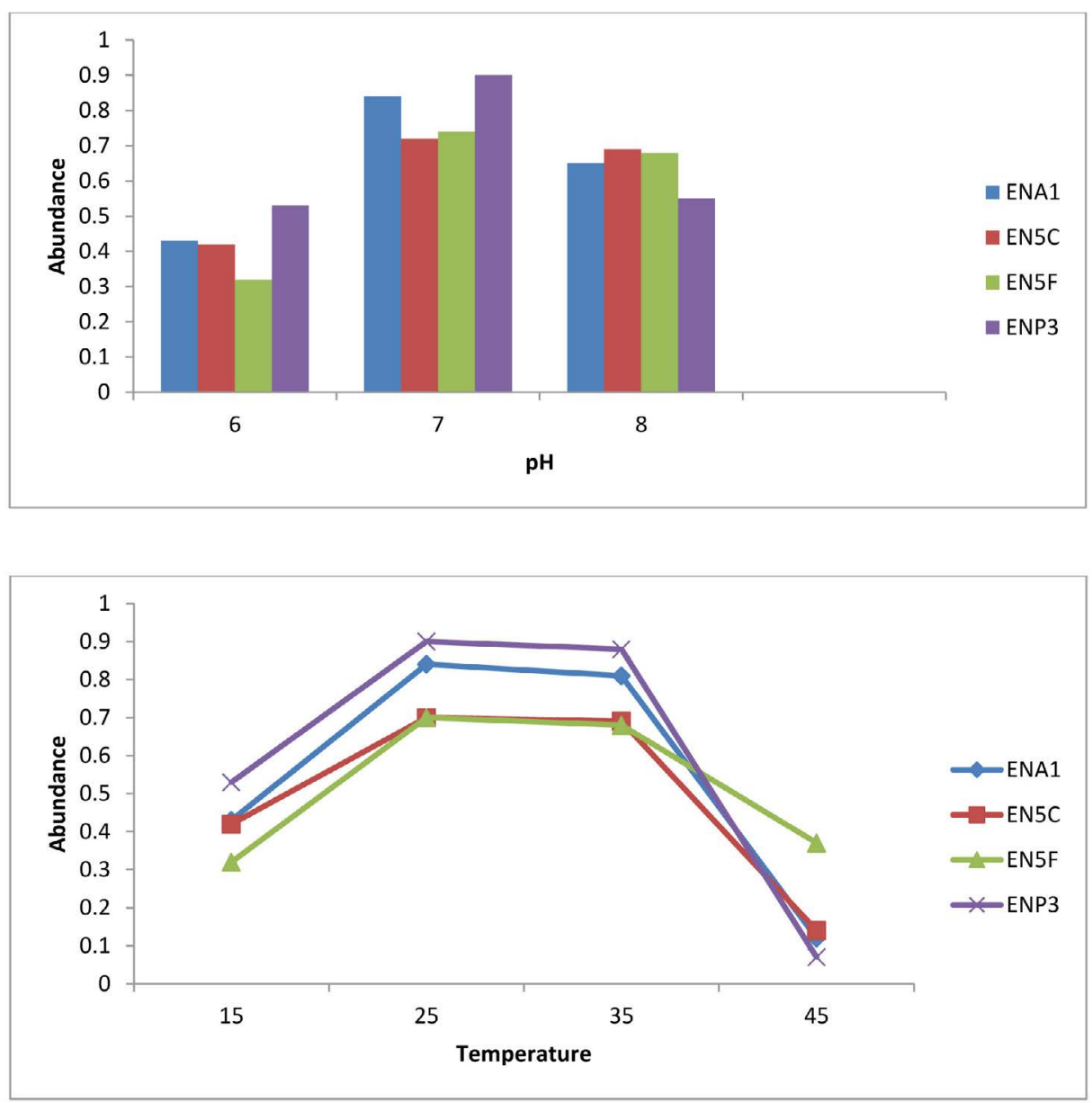

Fig. 1. a) Growth of organisms at different $\mathrm{pH}$ containing Monocrotophos b) Growth of organisms at different temperature containing Monocrotophos 
Visakhapatnam district. Initially the organisms were enriched by growing them in MSM containing Monocrotophos as the sole source of carbon. The influence of varying $\mathrm{pH}$ and temperatures on the organisms were determined (Fig. 1 a \& b) and it was observed that all the isolates have shown fair growth at $\mathrm{pH} 7$ and between $20-35^{\circ} \mathrm{C}$ temperature range. Table 3 depicts the tolerance levels of these four organisms for Monocrotophos from 10ppm to 500ppm. The data shows that Bacillus aryabhattai was able to grow actively up to 300ppm, Bacillusdrentensis and Bacillus firmus up to100ppm while Staphylococcusvitulinus can grow up to 60ppmof pesticide concentration. The average degradation potential of the organisms is shown in Table 4. Growth kinetics of the selected organisms (Fig. 2 a-d) in the presence and absence of Monocrotophos shows that the organisms are able to utilize Monocrotophos as the carbon source. Also the ability of Cow dung manure and NPK on the growth of organisms indicate that the organisms can grow well utilizing both NPK and Cow dung manure but the maximum growth is observed with NPK and this may be attributed to direct availability of large amount of extra nutrient source. The degradation potential studies of individual isolates and consortium for Monocrotophos (Fig. 3) and the degradation efficacy on the addition of Cow Dung Manure (Fig. 4) and NPK (Fig. 5) shows that all organisms can degrade the pesticide at a higher rate when NPK is added to the medium. Besides, the control sample containing Cow dung manure and Monocrotophos without the addition of consortia has shown 15
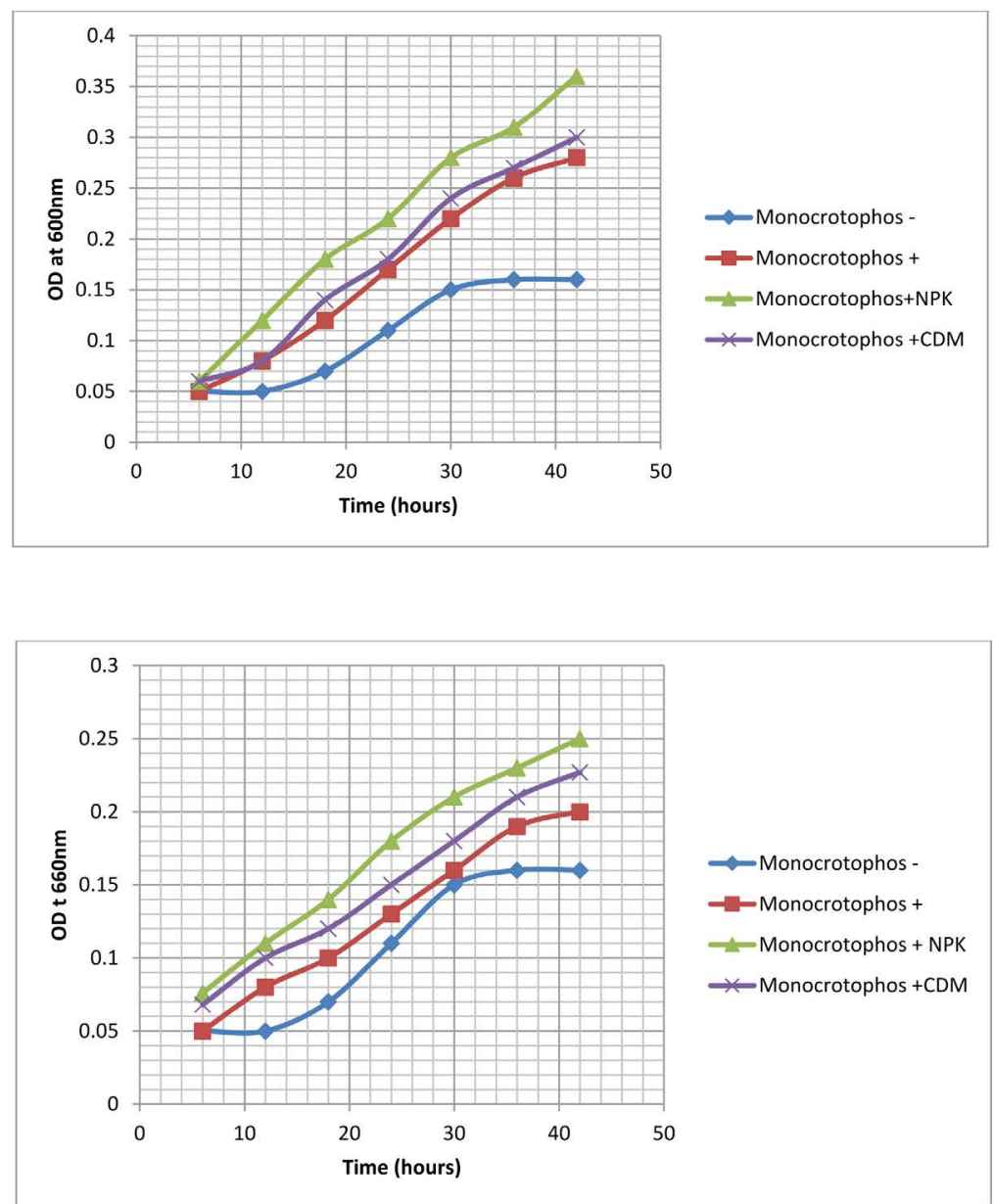

Fig. 2. Growth kinetics of organisms in the presence of Monocrotophos, without Monocrotophos, with addition of NPK, and Cow Dung Manure (CDM). a) ENP3; b) ENA1; c) EN5C; d)EN5F. 
\% degradation capacity and this may be due to the indigenous organisms present in cow dung manure. Among the individual isolates studied for the degradation of Monocrotophos B.aryabhattai is able to degrade Monocrotophos faster followed by B.drentensis, B. firmus and S.vitulinus. The degradation potential in consortium of these isolates is found to be faster compared to individual organisms.

\section{LC-MS analysis of soil sample}

The LC-MS spectra of soil sample spiked with Monocrotophos at Oh (Fig. 6a) showed a major peak at $\mathrm{m} / \mathrm{z} 223.6$ with a retention time of $3.3 \mathrm{~min}$, indicating the presence of maximum conc. of Monocrotophos. After 4 days, the LC-MS data for the same soil sample (Fig. 6b) showed a major peak at $\mathrm{m} / \mathrm{z} 209.2$ with a retention time of 2.9 minPeak followed by another peak at $\mathrm{m} / \mathrm{z}$ 223.6with a retention time of 3.3 min with an intensity of about $43 \%$. This clearly shows that after 4 days, $57 \%$ of the pesticide got degraded indicating the presence of less amount of Monocrotophos. The LC-MS spectra for the same soil sample after 8 days (Fig. $6 \mathrm{c}$ ) showed a major peak at $\mathrm{m} / \mathrm{z} 170.0$ with a retention time of 2.4 $\mathrm{min}$. but the Monocrotophos peak appeared with

Table 4. Degradation efficacy of the Isolates for Monocrotophos obtained by Enrichment culture

\begin{tabular}{ll}
\hline ENA1 & $0.430 \pm 0.083$ \\
EN5C & $0.426 \pm 0.102$ \\
EN5F & $0.593 \pm 0.093$ \\
ENP3 & $0.496 \pm 0.091$ \\
Consortia & $0.184 \pm 0.153$
\end{tabular}

Mean and SD of OD are value of three experiments.
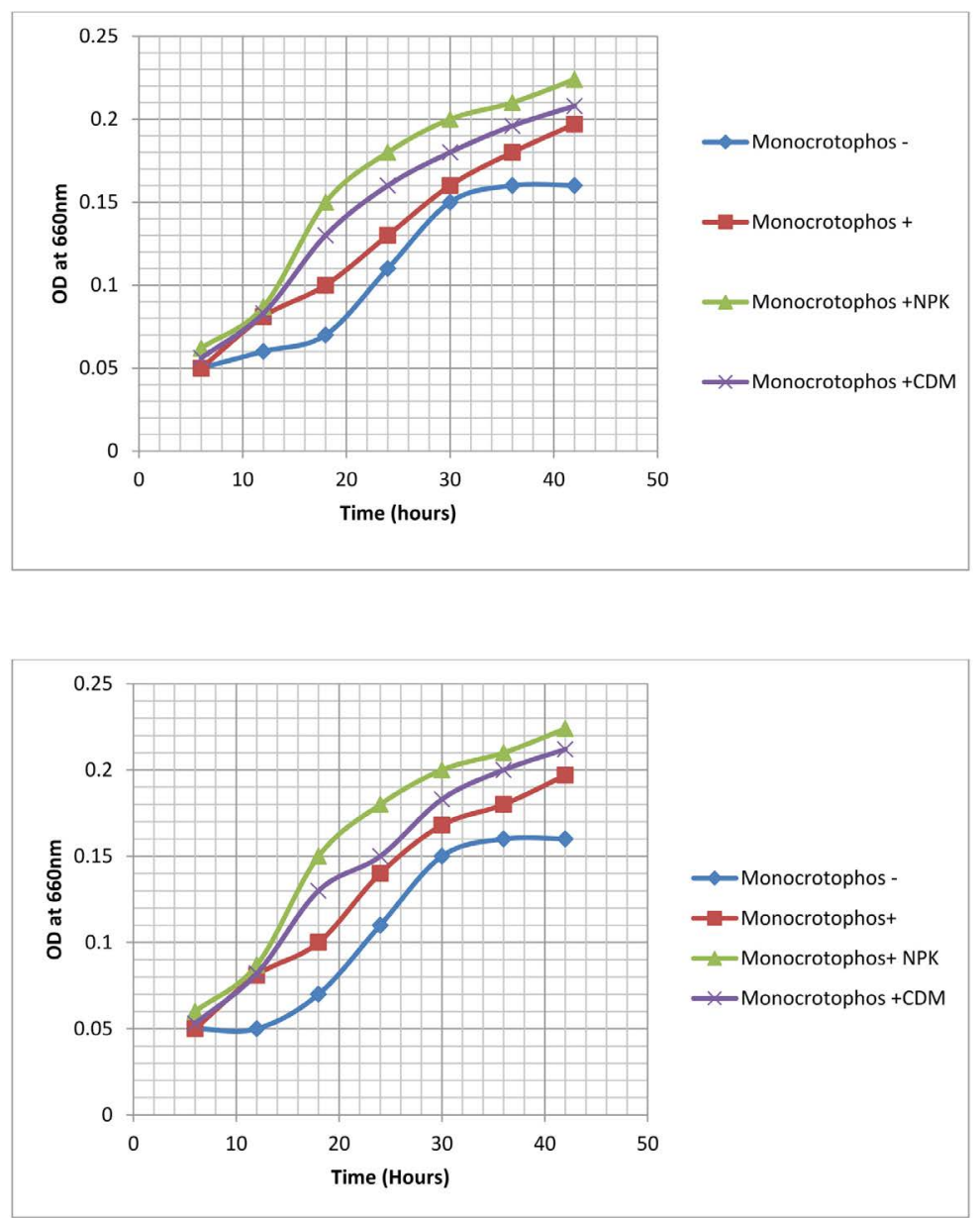

Fig. 3. Degradation potential of individual Isolates and Consortium for Monocrotophos. 

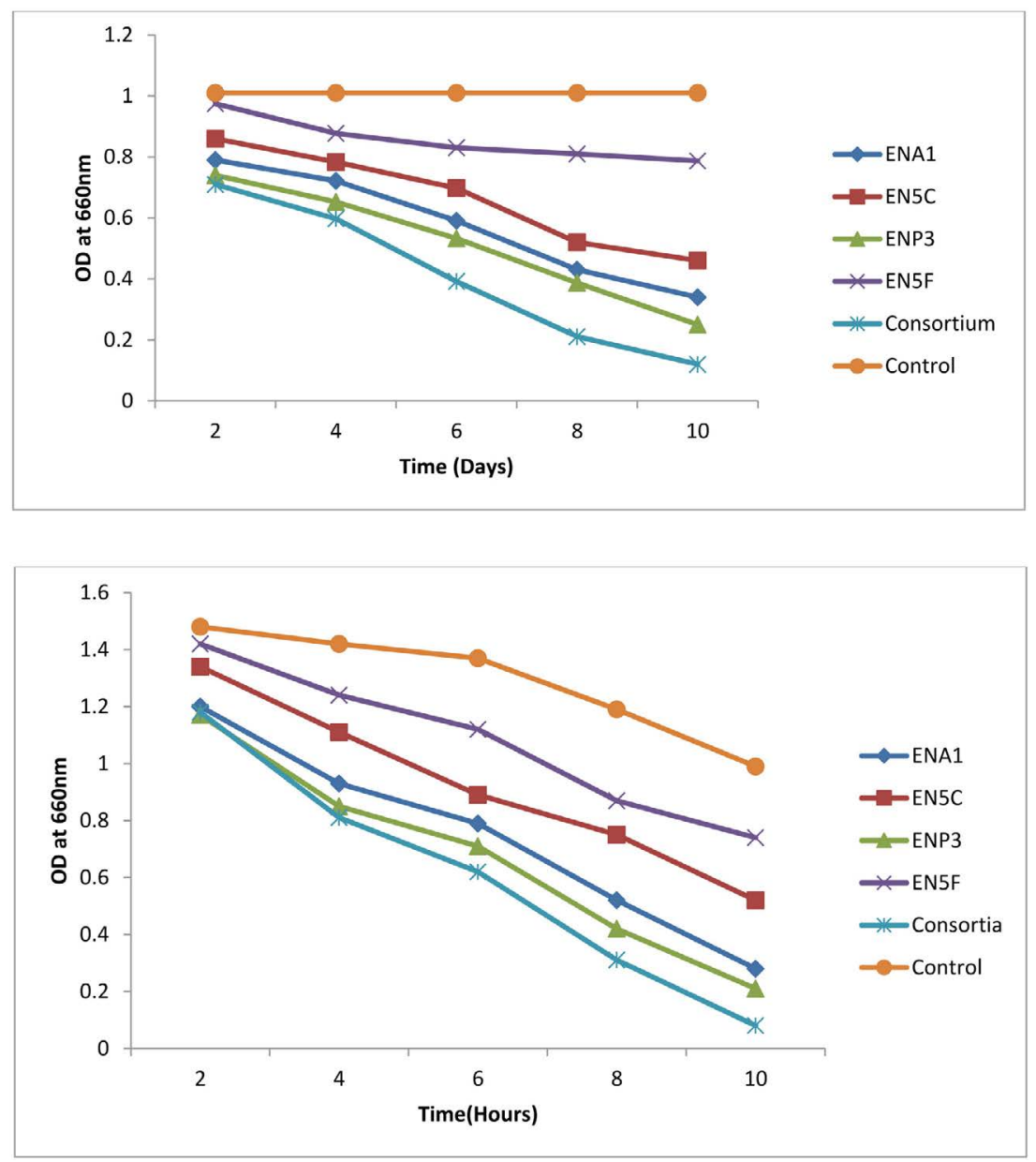

Fig. 4. Degradation potential of individual isolates and consortium with Cow dung manure for Monocrotophos

an intensity of about $17 \%$ only. This shows that after 8 days $83 \%$ of the pesticide got degraded. After 12 days (Fig. 6d), the LC-MS data showed a major peak at $\mathrm{m} / \mathrm{z} 126.2$ with a retention time of $1.8 \mathrm{~min}$. The mass 126.2 shows that the pesticide has degraded to Di methyl phosphoric acid ${ }^{17}$. No semblance of $\mathrm{m} / \mathrm{z} 223.6$ is observed indicating complete degradation of the pesticide. The soil sample after 16 days (Fig. 6e) showed a major peak at $\mathrm{m} / \mathrm{z} 96.0$ with a retention time of $1 \mathrm{~min}$. It is also observed that there are two major peaks at $\mathrm{m} / \mathrm{z} 114$ and $\mathrm{m} / \mathrm{z} 126.2$ with retention times of 1.3 $\mathrm{min}$ and $1.7 \mathrm{~min}$. respectively. Mass numbers 114 and 126 indicate the degradation of the pesticide to N-methyl acetoacetamide ${ }^{18,19,20}$ and Di methyl phosphoric acid. The LC-MS spectra for the control soil sample after 16 days (Fig. 6f) showed a peak at $\mathrm{m} / \mathrm{z} 223.0$ with a retention time of $3.1 \mathrm{~min}$. and the intensity is around $73 \%$. This may be due to abiotic degradation of the compound.

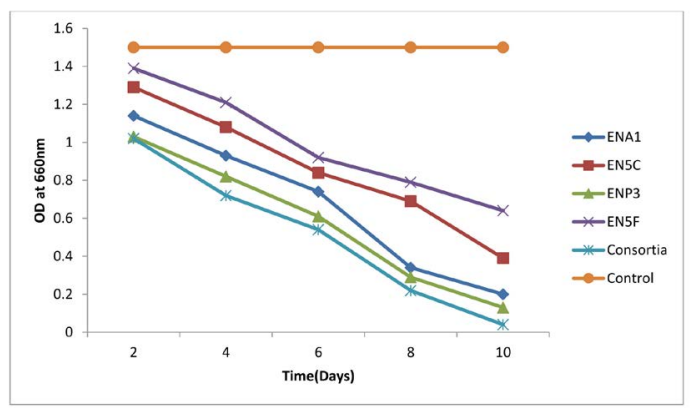

Fig. 5. Degradation potential of individual isolates and consortium with NPK for Monocrotophos 

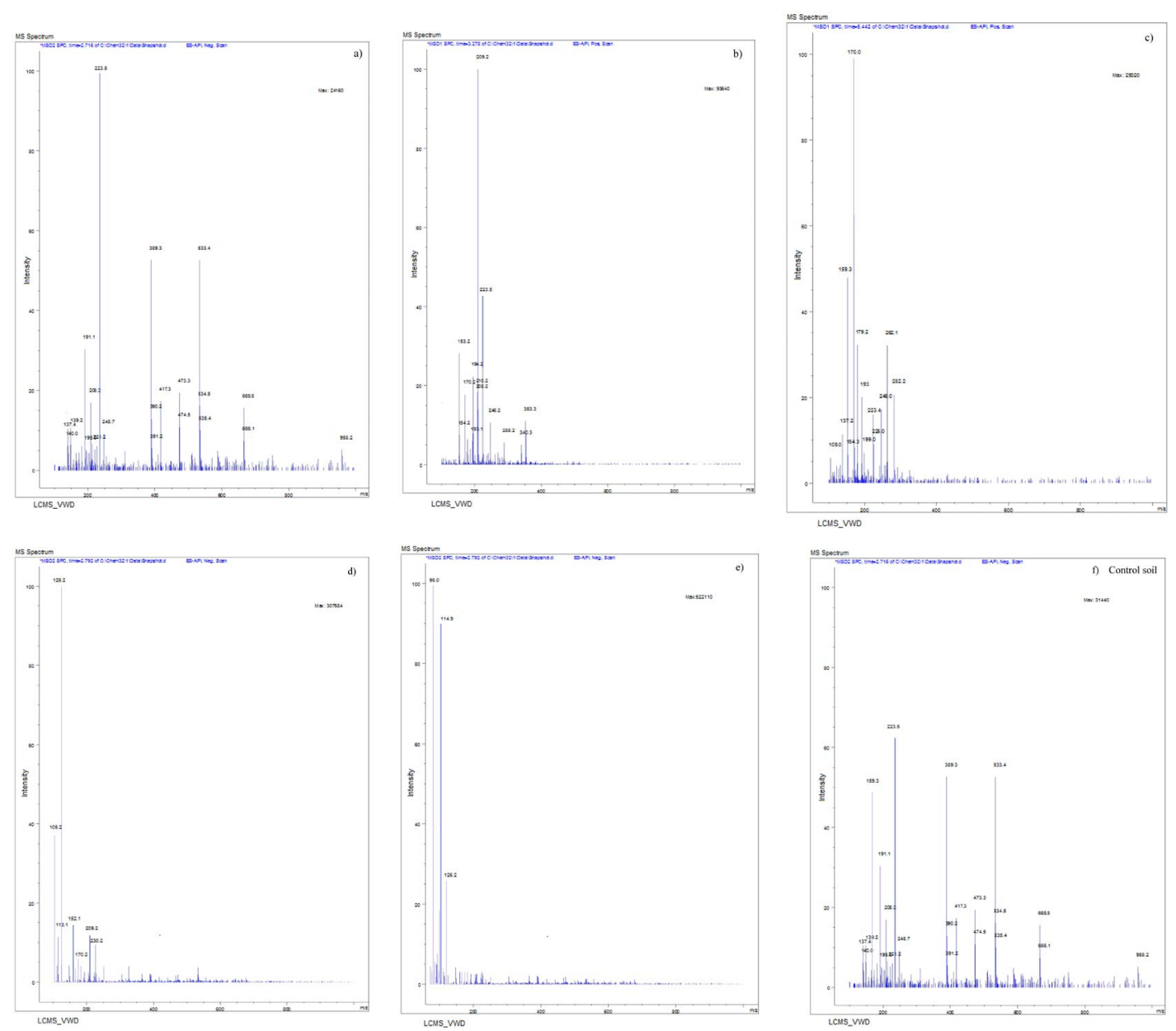

Fig. 6. LC-MS analysis of the degradation study of Moocrotophos a. $0^{\text {th }}$ h, b. $4^{\text {th }}$ days, c. $8^{\text {th }}$ days, d. $12^{\text {th }}$ days, e. $16^{\text {th }}$ day, f. $16^{\text {th }}$ day Control soil.

\section{DISCUSSION}

To isolate potential Monocrotophos degrading organism bacterial consortium was developed from agricultural soil by selective enrichment technique by providing Monocrotophos as the sole source of carbon. Degradation of Monocrotophos by consortium was found to be effective, this could be due to the synergistic effect of various bacterial isolates than degradation by individual organisms.

Bioremediation of Monocrotophos has been extensively studied and many potential bacterial strains have been isolated for the degradation of Monocrotophos. Organisms like Pseudomonas aeruginosa $\mathrm{F} 10 \mathrm{~B}$ and Clavibactermichiganensessp. insidiosum SBL $11^{21}$ have shown to utilize Monocrotophos as a phosphorus source but not as a carbon source. Bacillus $s p$. Isolated from previously treated soil ${ }^{22}$ with Pseudomonas mendocina ${ }^{23}$ is studied to be the most efficient Monocrotophos degrader and its degrading capability is plasmid based. Pseudomonas sps, Arthrobactersps, B. megatherium, Arthrobacteratrocyaneus ${ }^{24}$ can utilize Monocrotophos as a sole source of carbon.

In the present study four organism sBacillus aryabhatta Strain ENP 3, Bacillus drentensis strain ENA1, Bacillus firmus Strain EN5C, and Staphylococcus vitulinus Strain EN5F were studied for their degradation capacities for Monocrotophos. In MSM media, the degradation potential of $B$. aryabhatta is found to be $74 \%$ followed by $B$. drentensis is $69 \%$ B. firmus, $59 \%$, and S. vitulinus $38 \%$. The degradation potential of B. aryabhattai B. drentensis and B. firmus and S. vitulinus increased by $10 \%$ on the addition of 
Cow dung manure and the degradation potential increased by $20-25 \%$ for B.drentensis, B.firmus, B. aryabhattai and S. vitulinus by the addition of NPK. Moreover the degradation potential of the consortium was found to be higher at about $70 \%$ and degradation potential increased for about $10 \%$ when Cow dung manure is added and $25 \%$ when NPK is added to the media. LC-MS analysis of soil sample suggests that the consortia were able to completely degrade Monocrotophos within 12 days. Intermediate compounds like N-methyl acetoacetamide and Di methyl phosphoric acid were detected. Degradation rate of the consortia in soil sample was observed to be nearly $80 \%$. The present study reveal that the degradation potential of the isolates follow in the order Bacillusaryabhatta Strain ENP 3> Bacillus drentensis strain ENA1> Bacillus firmus Strain EN5C > Staphylococcus vitulinus Strain EN5F The results of the present study reveal that these organisms have the potential to degrade pesticide Mono-crotophos. Further studies will throw more credible information on the practical application of these isolated organisms in degrading Monocrotophos in soil.

\section{ACKNOWLEDGEMENT}

One of the authors Miss Sri Lakshmi Balakrishnan is grateful to Department of Science and Technology (DST), Govt. of India for extending financial support in the form of Women Scientist Program. Thanks are due to DST-Promotion of University Research and Scientific Excellence programme and Department of Environmental Sciences of Andhra University for providing infrastructural facilities.

\section{CONFLICT OF INTERESTS} conflict of interest.

The authors declare that there are no

\section{REFERENCES}

1. Bharati, J.,Bhadbhade, SeemaS, Sarnaik, Pradnya, P., Kanekar. Bioremediation of an Industrial Effluent Containing Monocrotophos. Cur Microbiol, 2002; 45: 346-349. DOI: 10.1007/s00284-002-3681-1.

2. Miller, G. T. Sustaining the Earth, 6th edition. Thompson Learning, Inc. Pacific Grove, California, USA, 2004.

3. Senthilkumaar,S., Krishna,S.K., Kalaamani, P.Subburamaan, C.V., Ganapathysubramaniam, N. Adsorption of Organophosphorous Pesticides from Aqueous Solution Using, Wastes Jute Fiber Carbon.

\section{Mod Appl Sci, 2010; 4: 67-83.}

4. Bai,Y.H., Zhou,L.and Wang, J.Organophosphorous pesticides residues in market foods in Shaanxi area, China." Food Chem, 2006; 98: 240-260.

5. Varun Agarwal and Sumanta Das.Degradation of monocrotophos pesticides using the advanced oxidation method. J Environ Manage, 2014; 1(1): 2-10.

6. Janine Acero. Monocrotophos - toxicity, side effects, diseases and environmental impacts, PESTICIDES NEWS, 2017.

7. Brajesh, K. Singh and Allan Walker. Microbial degradation of organophosphorus compounds. FEMS Microbiol Rev., 2005; 30: 428-471.

8. Tomlin C. The Pesticide Manual. 12th edn. BCPC Publications, Surrey, UK, 2000.

9. WORLD HEALTH ORGANIZATION, GENEVA 1993.

10. Mylavarapu, R.S., Kennelley, E.D. UF/IFAS Extension soil testing laboratory (ESTL) Analytical Procedures and Training Manual, 2002; pp: 18.

11. Official Methods of Analysis, 16th Ed., AOAC INTERNATIONAL, Gaithersburg, MD, sec. 33.2.11, Method 991.20, 1995.

12. Bray, R. H., Kurtz,L. T. Determination of total, organic and available forms of phosphorus in soils. Soil Sci., 1945; 59: 39-45.

13. Black, C. A. Methods of soil analysis Part I Am. Soc. Agron. Inc. Publi. Madison Wisconsin USA, 1965.

14. PelczarMichael, J. and Reid Roger, D. Book Soil Science, 1958; 86(6): 355

15. Buchanan, R. E. and Gibbons, N. E., eds. Bergey's Manual of Determinative Bacteriology. 8th ed. Williams \& Wilkins Co., Baltimore, 1974.

16. GONG, Chun-ming. Microbial safety control of compost material with cow dung by heat treatment. Journal of Environmental sciences, 2007; 9 (8): 1014-1019.

17. Rosenberg, A. and Alexander, M. Microbial cleavage of various organophosphrous insecti-cides; Appl. Environ. Microbiol, 1979; 37: 886-891.

18. Beynon, K. I., Hutson, D. H. and Wright, A. N. The metabolism and degradation of vinyl phosphate insecticides. Res. Rev., 1973; 47: 55-142.

19. Hassal,A. K. "Organophosphorus Insecticides, in the Biochemistry and Uses of Pesticides", 1990; pp. 81-124.

20. Lee, P.W., Fukuto, J.M., Hernandez, H. and Stearns, S.M. Fate of monocrotophos in the environment. J Agricul Food Chem, 1990, 38(2): 567-573.

21. Singh, S. and Singh, D.K. Utilization of monocrotophos as phosphorus source by Pseudomonas aeruginosa F10B and Clavibacter-michiganense subsp. insidiosum SBL 11. Can. J. Microbiol., 2003; 49: 101-109.

22. Rangaswamy, V. and Venkateswaralu, K. Degradation of selected insecticides by bacteria isolated from soil. Bull. Environ. Contam. Toxicol, 1992; 49: 797-804.

23. Bhadbhade,B.J., Dhakephalkar, P. K., Sarnik, S.S. and Kanekar, P.P. Plasmid-associated biodegradation of an organophosphorus pesticide, monocrotophos, by Pseudomonas mendocina. Biotechol. Lett., 2002; a24: 647-650.

24. Bhadbhade, B.J, Sarnik, S. S. and Kanekar, P.P. Biomineralization of an organophosphorus pesticide, monocrotophos, by soil bacteria. J. Appl. Microbiol., 2002; 93: 224-234. 